\title{
Isolation of Anticancer Bioactive and In Vitro Evaluation of Antioxidant and Anticancer Activity of Cynodon dactylon (L). Pers
}

\section{Sai Koushik O, Srinivasa Babu P and Ramadoss Karthikeyan}

\section{Abstract}

Cynodon dactylon (L.) Pers. Graminae/Poaceae is called as Aruvam pillu in Tamil, Bermuda grass in English. A creeping herb rooting at the joints with smooth upward stem. It was distributed in all tropical and subtropical region of the world. The herb contains beta sitosterol, beta-carotene, vitamin C, palmitic acid, and triterpenoids. Alkaloids like ergonovine, ergonovivine, ferulic acid, syringic acid, vanillic acid. It is reported to have antiseptic, diuretic; It is a folk remedy for calculus, cancer, carbuncles, convulsions, cough, cramps, cystitis, and wounds. The aim of this research is to explore the antioxidant activity, leads to anticancer potential of this plant material. There were three different extracts used for the evaluation of this activity. In this, ethyl acetate and methanolic extracts showed sufficiently greater activity compared with the control in the study.

Keywords: Cynodon dactylon (pers.) leaves; Antioxidant activity; P-NDA method; MTT assay

Received: September 30, 2015, Accepted: December 01, 2015, Published: December 03, 2015
Corresponding author:

Ramadoss Karthikeyan

\section{$=$ rkcognosy@gmail.com}

Department of Pharmacognosy, Vignan Pharmacy College, Vadlamudi-522213. Andhra Pradesh, India.

Tel: 91-9966847127

Citation: Koushik OS, Babu PS, Karthikeyan R. Isolation of Anticancer Bioactive and In Vitro Evaluation of Antioxidant and Anticancer Activity of Cynodon dactylon (L). Pers. Transl Biomed. 2015, 6:3.

\section{Introduction}

Cancer, one of the most dreadful diseases, lasts to spread with increasing incidence. Statisticians estimate that more than 10 million new cases of cancer appearing worldwide, with over 6 million deaths in the year 2000. Since 1990 cancer incidence and mortality have increased $22 \%$ based on information until 2003, the four most frequently occurring cancers are cancer to lung, breast, colorectal and stomach and the four most deadly comprise lung, stomach, liver and colorectal cancers [1-5]. From 1940 to 2002 of all the available anti-cancer drugs upto $40 \%$ were natural products. Cynodon dactylon (L) pers. family (poaceae) commonly known as Bermuda grass or durva in Hindi is a weed. It is traditionally used for diabetes, anti-inflammatory, kidney problems, urinary disease, gastrointestinal disorder, constipation, abdominal pain and as a blood purifying agent [6]. Whole plant is used for-diuretic, dropsy, syphilis, wound infection, piles. The juice of this plant has astringent and can be applied externally to fresh wounds and cuts [7-9]. It is mainly employed in the treatment of catarrhal opthalmia, hysteria, epilepsy, insanity, chronic diarrhea and dysentery [8,9]. In the ancient era this plant is used as folk remedy for calcus, carbuncles, cough, hypertension, snake bites and gout [10-12]. The Ethanolic extract of aerial parts of Cynodon dactylon showed greater protection against convulsions induced by chemo convulsive agents in mice. The ethanolic extract of Cynodon dactylon has marked C.N.S depressant activity and anti-oxidant activity. Since there is no information on the phyto chemical constituents of $C$. dactylon leaves it was opted as the topic of this research. The aim of this research is to explore the antioxidant activity, leads to anticancer potential of this selected plant material. There were three different extracts used for the evaluation of this activity. In this ethyl acetate and methanolic extracts showed noteworthy activity compared with the control in the study.

\section{Materials and Methods}

\section{Collection and preparation of plant}

The leaves of $\boldsymbol{C}$. dactylon were collected from the open field of medicinal garden of Vignan Pharmacy College, Guntur district, Andhra Pradesh during the month of December. The collected samples were authenticated by Dr. G.V.S. Murthy scientist F \& Head office Botanical Survey of India (BSI), Coimbatore and the specimen was deposited in the department. From the plant leaves are separated and washed properly with water and are used for transverse section. 


\section{Physicochemical Studies}

\section{Foreign matter}

Weigh $100-500 \mathrm{~g}$ of the drug sample to be examined or the minimum quantity prescribed in the monograph, and spread it out in a thin layer. The foreign matter should be detected by inspection with the unaided eye or by the use of lens (6xs). Separate and weigh it and calculate the percentage present

$\%$ of foreign matter $=\frac{\text { amount of foreign matter } \times 100}{\text { amount of drug taken }}$

\section{Moisture content}

Place about $10 \mathrm{~g}$ of drug (without preliminary drying) after accurately weighing (accurately Weighed within $0.01 \mathrm{~g}$ ) it in a tarred evaporating dish. For example, for underground or un powdered drug, prepare about $10 \mathrm{~g}$ of the sample by shredding so that the parts are about $3 \mathrm{~mm}$ in thickness. Seeds and fruits, smaller than $3 \mathrm{~mm}$ should be cracked. Avoid the use of high speed mills in preparing the samples, and exercise care that no appreciable amount of moisture is lost during preparation and the portion taken is representative of the official sample. After placing the above said amount of the drug in the tarred evaporating dish dry at $105^{\circ} \mathrm{C}$ for 5 hours, and weigh. Continue the drying and weighing at one hour interval until difference between two successive weighing corresponds to not more than 0.25 per cent. Constant weight is reached when two consecutive weighings after drying for 30 minutes and cooling for 30 minutes in a desiccator, show not more than $0.01 \mathrm{~g}$ difference.

\section{Extractive values}

\section{Alcohol soluble extractive}

Macerate $5 \mathrm{~g}$ of the air dried drug, coarsely powdered, with 100 $\mathrm{ml}$ of Alcohol of the specified strength in a closed flask for twenty four hours, shaking frequently during six hours and allow it to stand for eighteen hours. Filter rapidly, taking precautions against loss of solvent, evaporate $25 \mathrm{ml}$ of the filtrate to dryness in a tared flat bottomed shallow dish, and dry at $105^{\circ} \mathrm{C}$ to constant weight and weigh. Calculate the percentage of alcohol soluble extractive with reference to the air dried drug.

\section{Water soluble extractive}

Macerate $5 \mathrm{~g}$ of the air dried drug, coarsely powdered, with $100 \mathrm{ml}$ of chloroform water of the specified strength in a closed flask for twenty four hours, shaking frequently during six hours and allow it to stand for eighteen hours. Filter rapidly, taking precautions against loss of solvent, evaporate $25 \mathrm{ml}$ of the filtrate to dryness in a tared flat bottomed shallow dish, and dry at $105^{\circ} \mathrm{C}$, to constant weight and weigh. Calculate the percentage of chloroform water soluble extractive with reference to the air dried drug.

\section{Determination of ash values}

\section{Total ash value}

Incinerate about 2 to $3 \mathrm{gm}$ accurately weighed, of the ground drug in a tared platinum or silica dish at a temperature not exceeding $450^{\circ} \mathrm{C}$ until it is free from carbon, cool and weigh. If a carbon free ash cannot be obtained in this way, exhaust the charred mass with hot water, collect the residue on an ash less filter paper, incinerate the residue and filter paper, add the filtrate, evaporate to dryness, and ignite at a temperature not exceeding $450^{\circ} \mathrm{C}$. Calculate the percentage of ash with reference to the air dried drug.

\section{Determination of water soluble ash}

Boil the ash for 5 minutes with $25 \mathrm{ml}$ of water, collect insoluble matter in a Gooch crucible or on an ash less filter paper, wash with hot water, and ignite for 15 minutes at a temperature not exceeding $450^{\circ} \mathrm{C}$. Substract the weight of the insoluble matter from the weight of the ash. Calculate the percentage of watersoluble ash with reference to the air dried drug.

\section{Determination of acid insoluble ash}

Boil the ash obtained in total ash for 5 minutes with $25 \mathrm{ml}$ of dilute hydrochloric acid, collect the insoluble matter in a Gooch crucible or on an ash less filter paper, wash with hot water and ignite to constant weight. Calculate the percentage of acid-insoluble ash with reference to the air dried drug.

\section{Determination of sulphated ash}

Weigh $1 \mathrm{gm}$ of fresh powder in a Gooch crucible and ignite it at $600^{\circ} \mathrm{C}$ for 10 mins remove the crucible and add $10 \mathrm{ml}$ of sulphuric acid and again ignite for 10 mins at $600^{\circ} \mathrm{C}$. Remove and calculate the percentage of sulphated ash with reference to the air dried drug.

\section{Preliminary phyto-chemical screening}

The preliminary phytochemical screening was done with the standard protocol [13].

\section{Isolation of Antioxidant Bioactive Agent by Preparative TLC Method}

\section{Preparation of Reagents and Standards}

\section{Mobile phase}

To 65 parts of water 34 parts of methanol and 1 part of glacial acetic acid was mixed to get one litre of the mobile phase. The mobile phase was then filtered through $0.22 \mu \mathrm{m}$ nylon membrane vacuum filtration and degassed by sonication.

\section{Preparation of Standard Solutions}

A standard stock solution was prepared by dissolving $100 \mathrm{mg}$ of P-coumaric acid in $100 \mathrm{ml}$ volumetric flask containing $60 \mathrm{ml}$ mobile phase, then sonicated for about 10 minutes and made up to 100 $\mathrm{mL}$ with mobile phase to get the primary standard stock solution containing $1000 \mu \mathrm{g} / \mathrm{mL}$ of P-coumaric acid. Working standard solutions were prepared by further dilution with mobile phase. 


\section{Preparative TLC for Purification}

A streak of crude extract was applied manually on a preparative TLC glass plate $(20 \mathrm{~cm} \times 20 \mathrm{~cm} ; 1500 \mathrm{~m}$ thickness) with inorganic fluorescent indicator binder (Analtech, Sigma-Aldrich, Steinheim, Germany). After air drying, the plate was developed, using the same mobile phase as used in the analytical TLC, in a presaturated glass chamber. In each experiment, two plates were used in parallel. One of the plates from each set of experiment was sprayed with as described above, and the bands were scraped off carefully from the plate. The scratched sample was dissolved in HPLC grade methanol and centrifuged at $12000 \mathrm{rpm}$ for $15 \mathrm{~min}$ in order to remove silica. The supernatant was collected, filtered from $0.22 \mathrm{~m}$ filter, and dried under reduced pressure. Further, all the dried samples were passed under nitrogen gas for $5 \mathrm{~min}$ and then dissolved in methanol for further characterization [12-14].

\section{Characterization of Purified Compound}

The UV spectrum of the purified compound was recorded from 190 to $600 \mathrm{~nm}$ on a ELICO double beam UV-visible spectrophotometer. ESI mass spectra was acquired from isolated compound and characterised. Proton nuclear magnetic resonance spectra were acquired using NMR spectrometer $\left(400 \mathrm{MH}_{\mathrm{z}}\right)$ employing TMS as an internal standard and deuterated methanol was used as solvent.

\section{Biological Screening}

\section{Antioxidant activity by p-nda (p-nitroso dimethyl aniline) radical scavenging method}

To a solution containing ferric chloride $(0.1 \mathrm{mM}, 0.5 \mathrm{ml})$, EDTA (0.1 $\mathrm{mM}, 0.5 \mathrm{ml})$, ascorbic acid $(0.1 \mathrm{mM}, 0.5 \mathrm{ml})$, hydrogen peroxide $(2 \mathrm{mM}, 0.5 \mathrm{ml}$ ) and $\mathrm{p}$-nitroso added various concentrations of the test compounds in distilled DMSO or dissolving solvent or alcohol to produce a final volume of $3 \mathrm{ml}$. Absorbance was measured at $440 \mathrm{~nm}[14]$.

$\mathrm{p}-\mathrm{NDA}$ radical scavenging activity $(\%)=\frac{[\mathrm{Abs}(\text { standard })-\mathrm{Abs}(\text { sample })]}{\mathrm{Abs}(\text { standard })} \times 100$

\section{Anticancer Activity}

\section{MTT assay}

This Colorimetric assay is based on the capacity of Mitochondria succinate dehydrogenase enzymes in living cells to reduce the yellow water soluble substrate 3-(4, 5-dimethyl thiazol-2-yl)-2, 5-diphenyl tetrazolium bromide (MTT) into an insoluble, colored formazan product which is measured spectrophotometrically. Since reduction of MTT can only occur in metabolically active cells, the level of activity is a measure of the viability of the cells.

\section{Procedure}

The monolayer cell culture was trypsinized and the cell count was adjusted to 3 -lakhcells/ $\mathrm{ml}$ using medium containing $10 \%$ newborn calf serum. To each well of 96 well microtitres plates, $0.1 \mathrm{ml}$ of diluted cell suspension was added. After 24 hours, when the monolayer formed the supernatant was flicked off and 100 $\mu \mathrm{l}$ of different test sample were added to the cells in microtitre plates and kept for incubation at $37^{\circ} \mathrm{C}$ in $5 \% \mathrm{CO}_{2}$ incubator for 72 hour and cells were periodically checked for granularity, shrinkage, swelling. After 72 hour, the sample solution in wells was flicked off and $50 \mu \mathrm{l}$ of MTT dye was added to each well. The plates were gently shaken and incubated for 4 hours at $37^{\circ} \mathrm{C}$ in $5 \% \mathrm{CO}_{2}$ incubator. The supernatant was removed, 50 $\mu \mathrm{l}$ of Propanol was added, and the lates were gently shaken to solubilize the formed formazan. The absorbance was measured using a microplate reader at a wavelength of $490 \mathrm{~nm}$. The percentage growth inhibition was calculated using the formula below: The percentage growth inhibition was calculated using following formula,

$$
\% \text { cell inhibition }=100-\{(\text { At-Ab) } /(A c-A b)\} \times 100
$$

Where

At=Absorbance value of test compound

$A b=A b s o r b a n c e$ value of blank

$A c=A b s o r b a n c e$ value of control

\section{Statistical analysis}

The calculation parts in these studies are calculated by EXCEL sheet and prism graph pad 2.1 software used to know the inhibitory concentration $\left(\mathrm{IC}_{50}\right)$. Remaining all other calculations are done with specific formulas mentioned in the respective part of the study.

\section{Results and Discussions}

\section{Physicochemical constant}

Determination of Physicochemical constants is performed as per the standard protocol followed in the Ayurvedic pharmacopoeia. The values are tabulated in Tables 1 and 2. The foreign matter adulterated in one gram powder was found to be $1 \%$. The moisture content of the powdered drug was found to be $0.1 \%$ (Table 3).

\section{Preparative TLC method}

Preparative TLC method is shown in Figures 1-4 and Tables 4 and 5.

\section{Biological screening}

Biological screening is shown in Figures 5-7 and Table 6.

\section{Anticancer activity}

Anticancer activity is shown in Figure 8 and Table 7. 


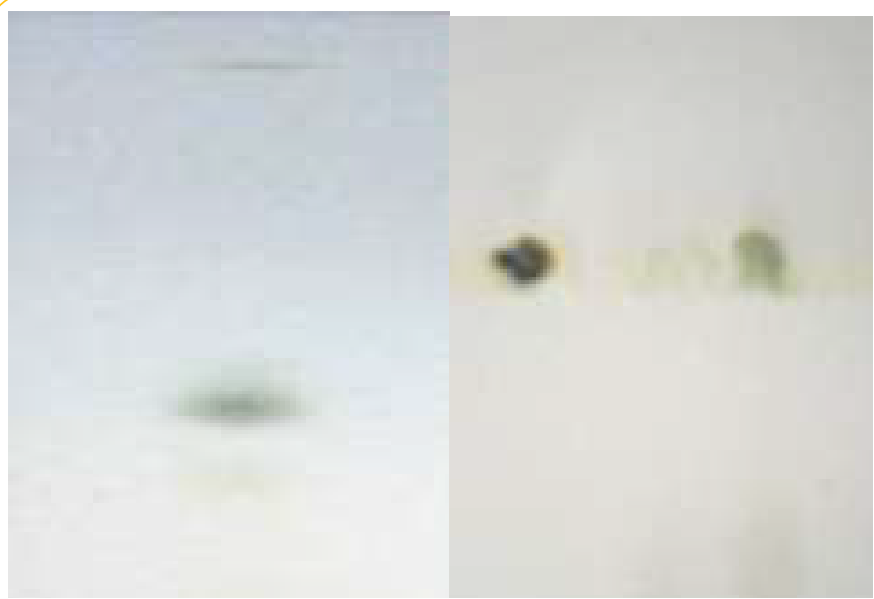

Figure 1 (a) chromatogram showing identification of Hydroxycinnamicacid standard, (b) Separation of Hydroxycinnamicacid in methanolic extract of durva grass.

Table 1 Different extractive values.

\begin{tabular}{|c|c|}
\hline Extractive value & Values \\
\hline Alcohol soluble extraction & $0.08 \%$ \\
\hline Water soluble extraction & $0.13 \%$ \\
\hline
\end{tabular}

Table 2 Different ash values of Cynadon dactylon.

\begin{tabular}{|c|c|}
\hline ASH VALUES & In\% \\
\hline Total ash value & $9.1 \%$ \\
\hline Acid insoluble ash value(dil.Hcl) & $3.7 \%$ \\
\hline Sulphated ash value (H SO ) & $19.18 \%$ \\
\hline Water soluble ash value (H O) $^{-1}$ & $7.9 \%$ \\
\hline
\end{tabular}

\section{Discussion}

\section{Physicochemical study}

Study of physicochemical characters is an essential step in the standardization of any plant species. It gives preliminary idea about moisture content foreign material content, inorganic, organic and silica like substance. The obtained results are listed in Tables 1 and 2.

\section{Phytochemical screening}

Phytochemical screening is a mandatory study to know the occurrence of types of chemical group present in the various extract obtained from successive solvent extraction procedure. The physicochemical screening test results releases predominating alkaloid in also in extracts. The steroids, tannins, vitamin A and gums are moderately present. Whereas the carbohydrates, proteins, are present in negligible amount.

Preliminary phytochemical screening also includes separation of phytochemicals from the different extracts. Hence, the mathematical was taken for the separation of anticancer bioactive substance by thin layer chromatography. In this, chloroform: methanol: formic acid (85:10:5 v/v) has used on a mobile phase and the $\mathrm{Rf}$ value was found to be 0.55 . Further the preparative TLC was performed to separate the compound with same mobile phase and chromatographic conditions. The separated bioactive substance is in white colour amorphous powder.

\section{Characterization of purified compound}

The purified compound is characterized by using various spectral methods such as uv-visible spectrophotometer, ESImass spectroscopy and $\mathrm{H}^{1} \mathrm{NMR}$ (proton) for its conformation of structure of Hydroxycinnamic acid. The results are shown in Figures $\mathbf{3}$ and $\mathbf{4}$. The results are matching with the standard spectra of hydroxycinnamic acid, hence the separated compound is confirmed the hydroxycinnamic acid.

\section{Antioxidant activity}

The antioxidant activity was performed by two in- vitro methods such as p-NDA ( paranitroso dimethyl anilic acid) reducing power evaluation. The reducing power was related with antioxidant activity, Hence, it was essential to determine the reducing power of constituents to be explained the relationship between then antioxidant effect and then reducing power was evaluated with the reducing power of different extract concentrations such as $10,20,40,80 \mu \mathrm{g} / \mathrm{ml}$ was estimated the highest reducing power was observed in $80 \mu \mathrm{g} / \mathrm{ml}$ of methanolic extract correlation coefficient $\left(R^{2}\right)=0.405$ and for the standard vitamin $C$ is $\left(R^{2}\right)=0.592$.

The different extracts were evaluated for their antioxidant is comparison with the standard ascorbic acid in overall assay in general the methanolic extract exhibited significant antioxidant activity. The antioxidant activity was presented in Table 6.

\section{Anticancer activity (MTT assay)}

MTT assay also shows significant effect on k-562 cell. The results are tabulated in Table 7 and graphically represented in Figure 8. It was found that the $\%$ growth inhibition increasing with increasing concentration steadily up to $80 \mathrm{mg} / \mathrm{ml}$ on k-562 cell

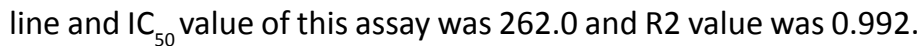
Now overall study evaluate that Cynodon dactylon has potential activity on k-562 cell so this drug has considerable anticancer activity on blood cancer. The anticancer activity was screened by 3-(4,5-dimethylthiazole-2-yl-7,5diphenyl tetrazoline bromide dye (MTT) assay method. The cell line study engaged the K-562 (chronc lymphocytic leukemia) for the assessment of anti-cancer property of the different extracts. The methanolic extract of Cynadon dactylon (pers) showed prominent anticancer activity against K-562 leukemic cells. The results are tabulated and presented in Table 7 and Figure 8. With the above findings, we concluded that the predicted antioxidant and anticancer activity is attributed, with the presence of hydroxycinnamic acid and other alkaloidal substances in the methanolic extract of Cynodon dactylon (L) (pers).

\section{Conclusion}

This study reports the successful separation of hydroxycinnamic acid from methanolic extract of Cynadon dactylon as a anticancer agent, and the same is proved with significant antioxidant activity and anticancer activity in Ethyl acetate and Methanol extracts of selected species of Cynodon dactylon $L$. 


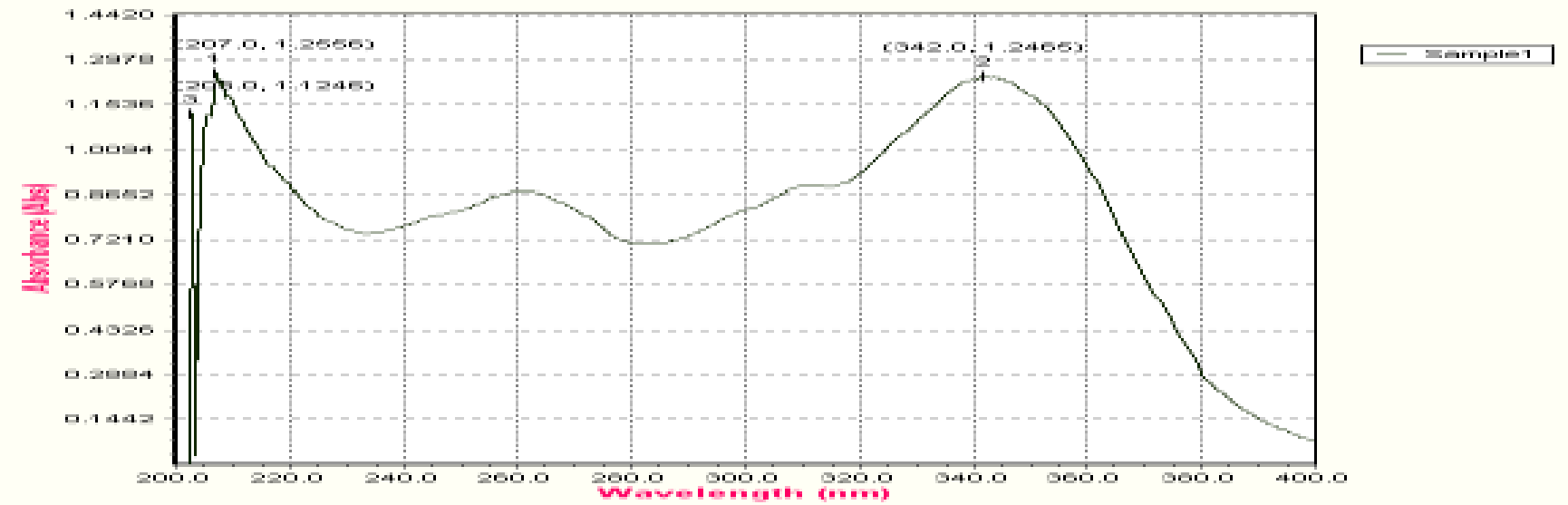

Figure 2 UV absorption spectrum of Hydroxycinnamicacid in methanol (Isolated from methanolic extract by preparative TLC).

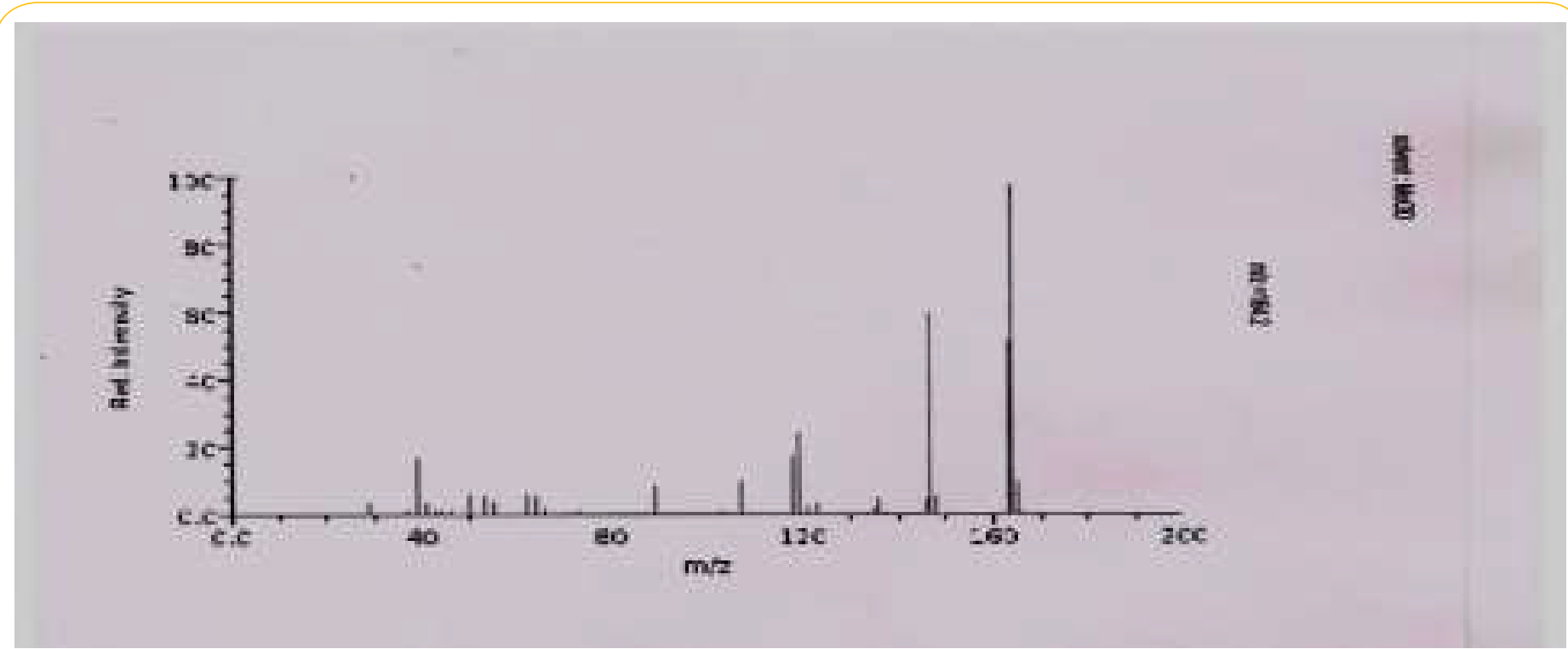

Figure 3 Mass spectra of Hydroxyl cinnamic acid isolated from methanolic extract of durva grass.

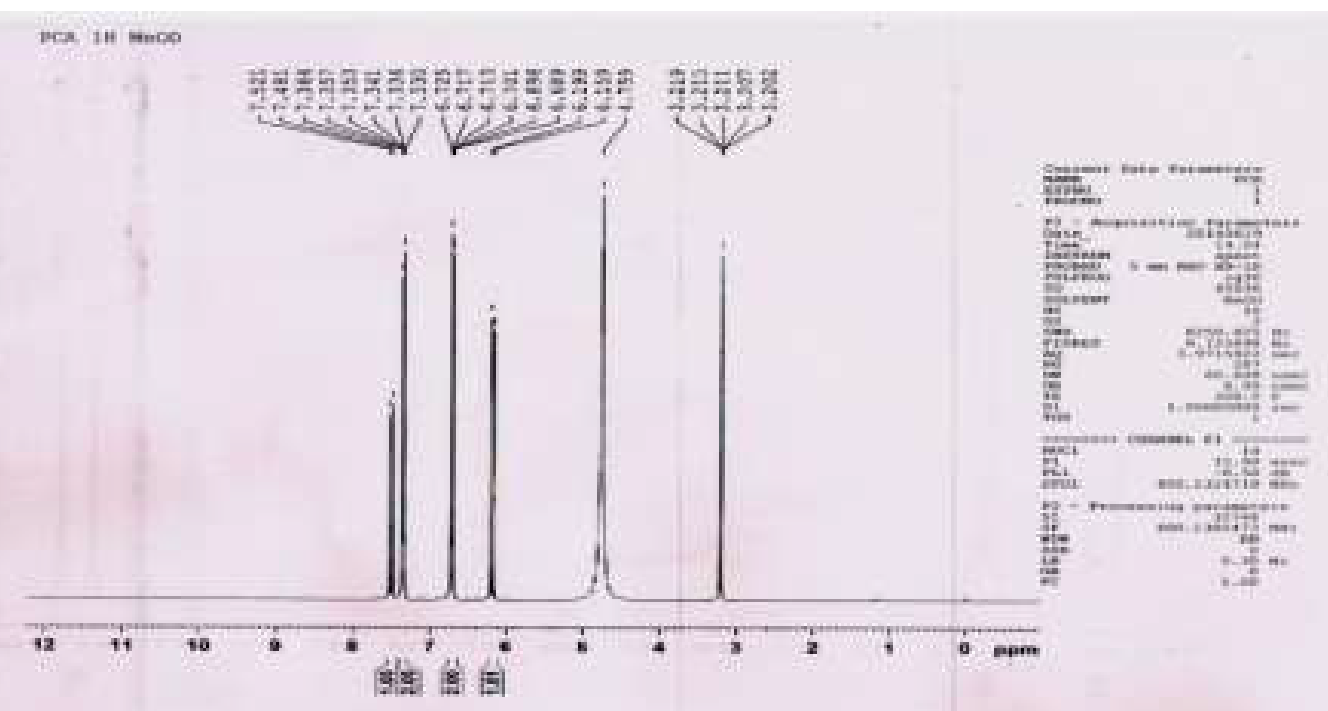

Figure $4 \quad H^{1}$ NMR spectra of Hydroxycinnamicacid isolated from methanolic extract. 


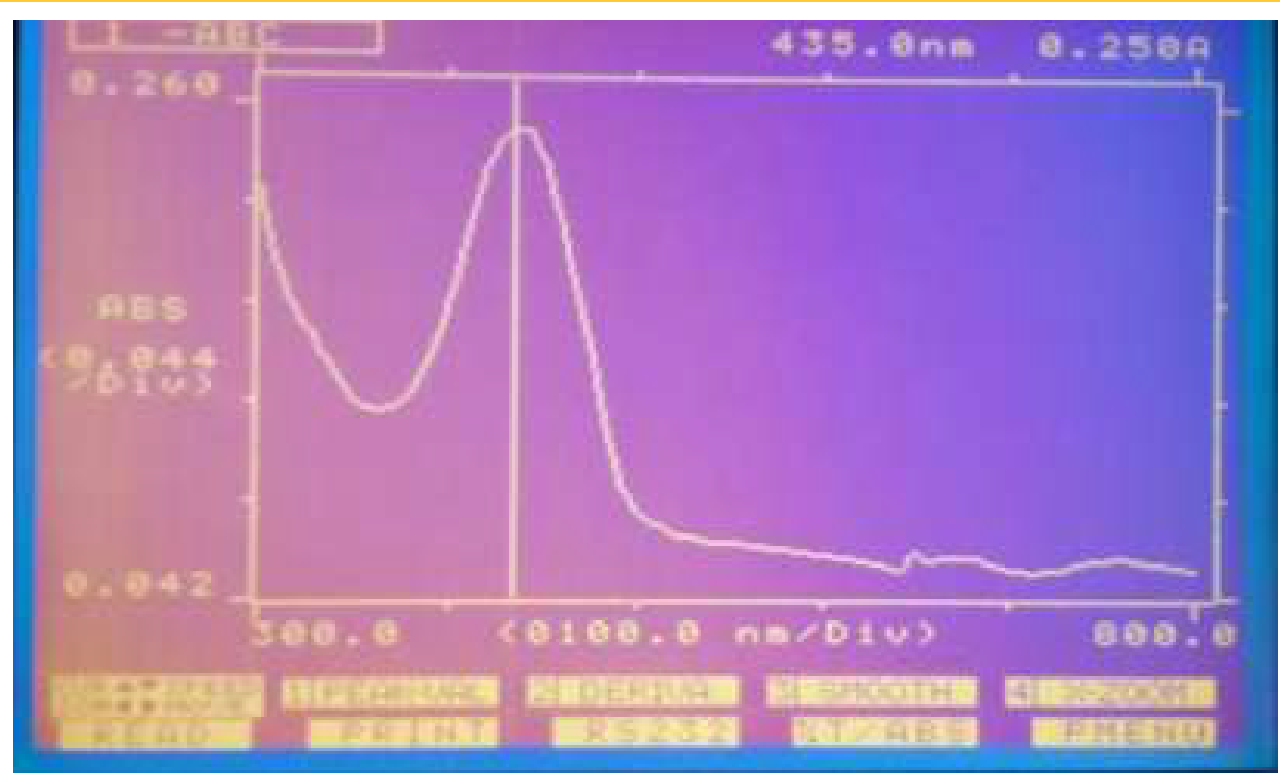

Figure 5 UV absorbtion spectra of ethyl acetate extract by p-NDA method.

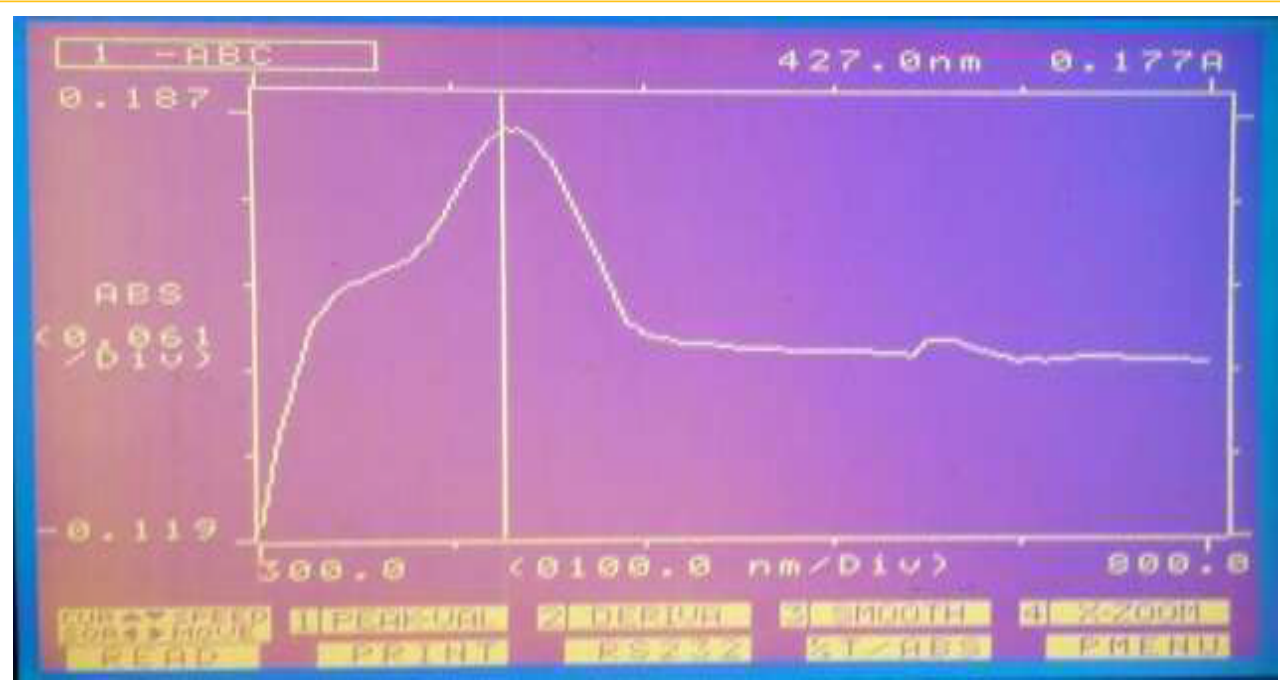

Figure 6 UV absorbtion spectra of methanol extract by P-NDA method.

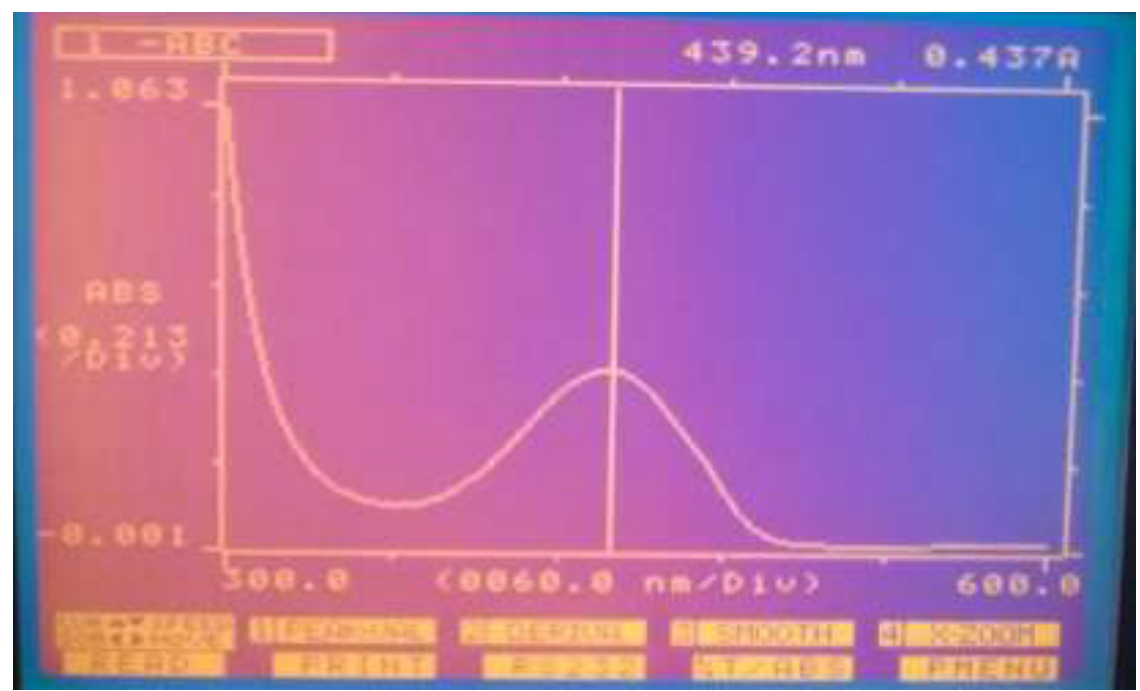

Figure 7 UV absorbtion spectra of water extract by P-NDA method. 


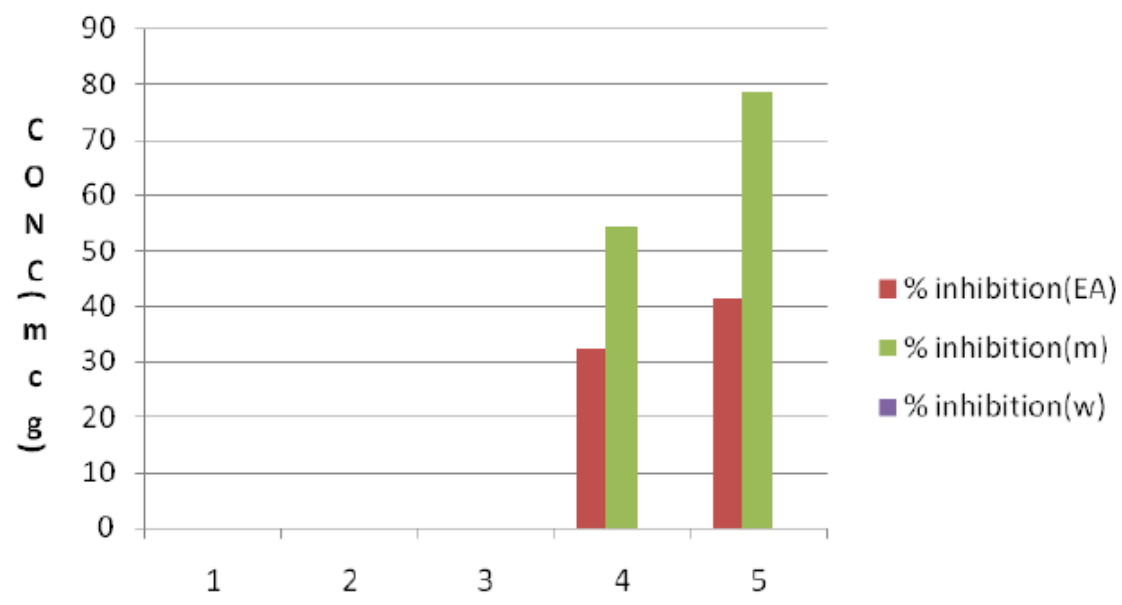

$\%$ Inhibition of growthof cancer cells

Figure 8 \% inhibition of growth of k-562chronic lymphocytic leukemia Cells.

Table 3 Preliminary phytochemical screening.

\begin{tabular}{|c|c|c|c|c|c|c|}
\hline $\begin{array}{l}\text { Name of the } \\
\text { phytoconstituent }\end{array}$ & Pet ether & n-hexane & Ethyl acetate & Chloroform & methanol & Water \\
\hline $\begin{array}{l}\text { Molischs test } \\
\text { (Carbohydrates) }\end{array}$ & - & - & + & - & - & + \\
\hline Test for gums & + & + & _ & _ & _ & + \\
\hline Test for mucilage & + & _ & _ & _- & _ & _ \\
\hline Biurets test (proteins) & _ & _ & _ & + & _ & _ \\
\hline $\begin{array}{l}\text { Ninhydrine } \\
\text { (amino acids) }\end{array}$ & - & - & - & - & - & + \\
\hline Salkowaskitest (steroid) & _ & _ & + & _- & + & + \\
\hline $\begin{array}{l}\text { Legals test } \\
\text { (cardiac glycosides) }\end{array}$ & - & - & - & - & - & - \\
\hline $\begin{array}{l}\text { Shinoda test } \\
\text { (flavanoids) }\end{array}$ & - & + & - & - & - & + \\
\hline $\begin{array}{l}\text { Dragondroff's test } \\
\text { (alkaloids) }\end{array}$ & + & + & + & + & + & + \\
\hline $\begin{array}{l}5 \% \mathrm{fecl}_{3} \text { solution and } \\
\text { (phenolic compounds) }\end{array}$ & - & - & + & - & + & + \\
\hline $\begin{array}{l}\text { Lead acetate solution } \\
\text { ( phenolic compounds) }\end{array}$ & - & - & - & - & + & + \\
\hline Test for vit $A$ & _ & + & + & + & _ & _ \\
\hline Test for vit D & - & - & - & - & - & - \\
\hline Test for vit C & + & + & + & + & - & + \\
\hline
\end{tabular}


Table 4 Molecular weights (mw) and important ions present in the mass spectra of Hydroxycinnamicacid in the examined plant extracts by ESI-MS.

\begin{tabular}{|c|c|c|c|}
\hline Compound & Molecular weight (MW) & Molecular ion [M] ${ }^{+}$ & Fragmented ions $(\mathrm{m} / \mathrm{z})$ \\
\hline Hydroxyl cinnamic acid & 164.2 & 164.2 & $\begin{array}{l}\text { 242(100), } 178 \text { (43), } 120(12.2), 40 \\
(19)\end{array}$ \\
\hline \multirow[t]{2}{*}{ Proton Number } & \multicolumn{3}{|c|}{ Chemical shift $\left(\delta_{p p m}\right)$} \\
\hline & $\begin{array}{c}\text { Theoretical } \\
\text { [29-30] }\end{array}$ & \multicolumn{2}{|c|}{ Experimental(Isolated compound) } \\
\hline 1 & 12.13 & \multicolumn{2}{|c|}{-- } \\
\hline 2 & 8.10 & \multicolumn{2}{|c|}{7.341} \\
\hline 3 & 6.97 & \multicolumn{2}{|c|}{6.689} \\
\hline 4 & 3.56 & \multicolumn{2}{|c|}{3.219} \\
\hline 5 & 7.06 & \multicolumn{2}{|c|}{6.725} \\
\hline 6 & 7.65 & \multicolumn{2}{|c|}{7.364} \\
\hline 7 & 6.44 & \multicolumn{2}{|c|}{6.199} \\
\hline 8 & 8.15 & \multicolumn{2}{|c|}{7.521} \\
\hline
\end{tabular}

Table 6 Antioxidant activity By P-NDA (P-Nitroso Dimethyl Aniline) Radical Scavenging Method.

\begin{tabular}{|c|c|c|c|c|}
\hline \multirow[b]{2}{*}{ Extracts } & \multicolumn{4}{|c|}{$\%$ Radical scavenging method concentration $(\mu \mathrm{g} / \mathrm{ml})$} \\
\hline & $\begin{array}{c}10 \mu \mathrm{g} / \mathrm{ml} \\
(\%)\end{array}$ & $\begin{array}{c}20 \mu \mathrm{g} / \mathrm{ml} \\
\text { (\%) }\end{array}$ & $\begin{array}{c}40 \mu \mathrm{g} / \mathrm{ml} \\
\text { (\%) }\end{array}$ & $\begin{array}{c}80 \mu \mathrm{g} / \mathrm{ml} \\
\text { (\%) }\end{array}$ \\
\hline Water & 89.96 & 21.47 & 82.39 & 80.98 \\
\hline Methanol & 68.48 & 55.80 & 55.63 & 35.91 \\
\hline Ethyl acetate & 55.98 & 59.50 & 48.76 & 8.45 \\
\hline Ascorbic acid & 74.30 & 76.40 & 78.20 & 79.01 \\
\hline
\end{tabular}

Table $7 \%$ inhibition of growth of k-562chronic lymphocytic leukemia Cells.

\begin{tabular}{|c|c|c|c|c|}
\hline $\begin{array}{c}\text { Name of the } \\
\text { extract }\end{array}$ & $\begin{array}{l}\text { Conc. } \\
\mu \mathrm{g} / \mathrm{ml}\end{array}$ & $\%$ inhibition & IC50 & $\mathbf{R}^{2}$ \\
\hline \multirow{4}{*}{ Ethyl Acetate } & 10 & 0 & \multirow{4}{*}{156} & \multirow{4}{*}{$0.742^{\prime}$} \\
\hline & 20 & 0 & & \\
\hline & 40 & $32.2^{*}$ & & \\
\hline & 80 & $41.2 *$ & & \\
\hline \multirow{4}{*}{ Methanol } & 10 & 0 & \multirow{4}{*}{262} & \multirow{4}{*}{$0.992 *$} \\
\hline & 20 & 0 & & \\
\hline & 40 & $54.2^{*}$ & & \\
\hline & 80 & $78.4^{*}$ & & \\
\hline \multirow{4}{*}{ Water } & 10 & 0 & \multirow{4}{*}{0} & \multirow{4}{*}{0.0} \\
\hline & 20 & 0 & & \\
\hline & 40 & 0 & & \\
\hline & 80 & 0 & & \\
\hline
\end{tabular}

\section{*Indicating the significance of activity}




\section{References}

Aruna D, Chakarvarthy K, Sarath Babu K (2013) Evaluation of Diuretic Activity of Cynodondactylon in Rats with Comparison of Hydrochlorothiazide. International Journal of Research in Pharmaceutical and Biomedical Sciences 4: 471-474.

Abhishek B, Anita Thakur (2012) Anthelmintic activity of Cynodondactylon. Journal of Pharmacognosy and Phytochemistry 1: 1-3.

3 Kipin Kumar G, Khosa R (2008) Analgesic and Anti-pyretic activity of aqueous extract of Cynodondactylon 12-18.

4 Jananie RK, Priya V, Vijayalakshmia K (2011) Determination of Bioactive Components of Cynodondactylon by GC-MS Analysis. New York Science Journal 4: 16-20.

Mansoor H, Ashraf M, NargisNaz F (2010) al-Qurainy anatomical adaptations of cynodondactylon (I.) pers., from the salt range pakistan, to salinitystress root and stem anatomy pak. J Bot 42: 279-289.

Noeman B (2009) AREF Effect of Bermuda Grass Cynodondactylon Extracts on Cotton Leaf Worm, Spodoptera littoralis Boisduval (Lepidoptera: Noctuidae) Egypt Acad J biolog Sci 2: 171-175.

Nayanatara AK, Akshatha A, Sharannya K (2012) Effect of Cynodondactylon extract on estrous cycle and reproductiveorgans in female wistar rats. International Journal of Analytical Pharmaceutical and Biomedical Sciences 1: 10-15.

8 Deepak B, Pradnya J, Vaishali U, Ashok B (2012) Aerial parts of Aqueous extract of Cynodondactylon shows hypotensive effect in high fructose treated wistar rats. International journal of research in pharmaceutical and biomedical sciences 3: 585-591.

Shivalingegowda KP, Satish S, Mahesh CM, Vijay K (2009) Study on the diuretic activity of Cynodondactylon root stalk extract in albino rats. Research J. Pharm and tech 2: 337-339.

10 Zabin K, Bagewadi, Siddanagouda RS, Praveen G (2014) Phyto constituents investigation by LC-MS and evaluation of anti-microbial and anti-pyretic properties of Cynodondactylon. International Journal of Pharmaceutical sciences and Research, 5: 2874-2889.

1 Payal D, Anis K (2012) Evaluation of wound healing potential of Cynodondactylon. Asian Journal of Pharmaceutical and Clinical Research 5: 161-164.

2 Soleimani M, Hajabbasi MA, Afyuni M, Charkhabi AH, Shariatmadari H (2009) Bioaccumulation of Nickel and Lead by Bermuda Grass (Cynodondactylon) and Tall Fescue (Festucaarundinacea) from Two Contaminated Soils. Caspian Journal of Environmental Sciences 2: 59-70.

Bhargava A, Rana AC (2014) Anti-inflammatory activity of Cynodondactylon Linn. In carrageenan induced paw edema in rats and its comparison with some standard. International Journal of Pharmaceutical Eruditions 3: 42-45.

Sivasangariramya S, Vijayanand N, Rathinavel S (2014) Antidiabetic activity of Cynodondactylon (I.) Pers. Extracts in alloxaninduced Rats. International Journal of Pharmacy and Pharmaceutical Sciences 6: 975-982. 